\title{
The Effect of Electoral and Economic Crimes on Sustainable Development in Cross River State, Nigeria
}

\author{
Ukwayi, J. K. \\ Lecturer, Department of Sociology, University of Calabar, Nigeria \\ Okpa, J. T. (Corresponding author) \\ Lecturer, Department of Sociology, University of Calabar, Nigeria
}

Received: July 10, 2017 Accepted: August 2, 2017 Published: August 10, 2017

doi:10.5296/ijssr.v5i2.11693

URL: http://dx.doi.org/10.5296/ijssr.v5i2.11693

\begin{abstract}
The survey examined the effect of electoral and economic crimes on sustainable development in Cross River State, Nigeria. Specifically, the study accessed the effect of election rigging and misappropriation of public funds on sustainable development in Cross River State. Two research questions were stated to guide the study. The study adopted the system theory. Survey research design was adopted in this study. An 18-item questionnaire captioned "Questionnaire on electoral, economic crimes and sustainable development" (QEESD) was designed by the researcher and used in gathering data for the study. Data were elicited from 384 respondents who were purposively selected from six (6) local government areas in the three Senatorial District of Cross River State. The respondents were selected from political parties, Independent National Electoral Commission (INEC) offices, religious groups, and the public. The generated data were presented using simple percentage, and chart. Findings revealed that election rigging and misappropriation of public funds affects sustainable development in Cross River state, Nigeria. The study recommended among others that political office holders should judiciously utilize public funds for programmes and projects that would positively affect the well-being of the citizens. In addition, rigging of election should be made a capital offence that should attract severe punishment like life imprisonment or death sentence.
\end{abstract}

Keywords: Electoral and economic, crime, election rigging, misappropriation of public funds, and sustainable development 


\section{Introduction}

Electoral and economic crime refers broadly to electoral and economic offences that violate existing financial and electoral laws, resulting to financial loss as well as electoral manipulation that affects the consolidation of socio-economic development. These crimes include a spectrum of outlaw activities such as fraud, election rigging, ballot box snatching, bribery and corruption, misappropriation of public funds, embezzlement, white-collar crime, tax evasion, money laundering, among others. This range of anti-social activities constitutes a universal social problem that not only threatens sustainable development, but also compromises the stability, transparency, and efficiency of financial and electoral systems, thus undermining the consolidation of development globally. Desta (2006), Dike (2008) reported that the spate of development in Nigeria is slow and sluggish. They blamed this slow socio-economic development on crimes such as money laundering, election rigging, bribery and corruption, misappropriation of public funds, embezzlement, white-collar crime, cybercrime and ballot box snatching.

Electoral and economic malpractices have significantly contributed to the backwardness and failure of good governance in Nigeria. These crimes do not only hinder fair competition among politicians, but also hinders economic growth and endangers the stability of democratic institutions. In addition, it destroys the moral values of the Nigerian society (Inokoba \& Ibegu, 2011). Accordingly, Mustapha (2008) posits that Nigeria as a country has not been able to implement policies which promote good governance and facilitate the development and success of the democratic process due to the existence of both high (Political corruption) and low levels (Bureaucratic corruption) of corruption. Ayobolu (2006) noted that electoral and economic crime is one of the many unsettled challenges that have decisively shuffled and distorted sustainable development in Nigeria. It has become a cog in the wheel of Nigeria's progress and development (Sachs, 2007).

The consequences of electoral and economic crime on governance and political stability especially election rigging and corruption, has been viewed by scholars as the bane of political stability and socio-economic development in Nigeria. Pogoson (2009) revealed that the regrettable corrupt practice by enemies and unbridled state plunderers, which is so widespread in Nigeria today, embodies the greatest human tsunami that has shackled on Nigeria's progress as a country since her freedom from colonialism. Against this backdrop, past military and civilian administration has enacted laws to outlaw all economic and electoral crimes. Famous among the range of anti-corruption institutions were War Against Indiscipline, National Committee on 419, Independent Corrupt Practices Commission and the most recent, the Economic and Financial Crimes Commission (Omadjohwofe, 2014).

A number of literature has shown the effect of financial crimes on the socio-economic development of Nigeria. While this report may be true, there is little or near absence of empirical evidence of the effect of electoral and economic crimes on sustainable development in Cross River State, Nigeria. In addition, review of existing literature on electoral and economic crimes and sustainable development in Cross River State shows that most literature focuses primarily on perception-based evidence with little empirical support. This study 
therefore sets to bridge these knowledge gaps by providing empirical evidence that would explain the effect of electoral and economic crimes on sustainable development in Cross River State, Nigeria. The following research questions were put forward to guide the study:

(i) To what extent does election rigging affect sustainable development in Cross River State?

(ii) How does misappropriation of public funds affect sustainable development in Cross River State?

\subsection{Objectives of the study}

The main objective of this study is to access the effect of electoral and economic crimes on sustainable development in Cross River State, Nigeria. Specifically, the study sought to:

(i) Determine the effect of election rigging on sustainable development in Cross River State.

(ii) Examine the effect of misappropriation of public funds on sustainable development in Cross River State.

\subsection{Significance of the Study}

The findings from this study are expected to be relevant to sociologists, criminologists, policy makers, politicians, researchers and experts in issues relating to economic and electoral crimes. Sociologists and criminologists will find the study most expedient, as the findings are expected to bring about a better understanding of the varied dimensions of economic and electoral crimes and its effect on sustainable development. Obviously, there exists a major gap in the domain of public policy for the effective control of economic and electoral crimes. Findings from this study are envisaged to provide information for effective management of such lapses.

Also the findings of this study are envisaged to be useful to government agencies as it will provide baseline data for designing appropriate goal-oriented policies and approaches that would improve on the strategies used in fighting economic and electoral crimes in Nigeria. The study would further serve as a baseline study for future research endeavours. More so, researchers intending to or already conducting a similar study in other locations or on a broader scope may use the findings of this study as a reference material for their studies.

\subsection{Scope of the Study}

The study examined the effect of electoral and economic crimes on sustainable development in Cross River State, Nigeria. The content scope of the study was restricted to misappropriation of public funds, election rigging, and sustainable development. The study was further delimited to six (6) local government areas selected from the three Senatorial Districts of Cross River State, Nigeria.

\section{Literature Review and Theoretical Framework}

\subsection{Election Rigging and Sustainable Development}


Rigging of election in Nigeria has persisted and growing in magnitude. It has grown into an indispensable way of life, as it has characterised previous elections in Nigeria (Okpa and Ukwayi, 2017). Rigging of election has become so entrenched in the minds of corrupt politicians and their supporters as they covertly and overtly discuss about it, make adequate plans for it, and challenge any force that wants to stop them from engaging in it during election (Omadjohwofe, 2014). According to ACID (2013), the failure of politicians and their supporters to abide by electoral laws and play the game by the rules has partly been responsible for the enthronement of bad leadership and military intervention in politics, over the years. The intervention of military in politics has resulted to political instability; assassination of political opponents, conflicts, increased cost in conduction of elections, thuggery, arson, and intimidation of political opponent. These electoral evils have created unhealthy political atmosphere that negatively affects sustainable development.

Electoral malpractices such as rigging have been one of the impediments to sustainable development. It has led to political instability and has affected all spectrum of Nigeria's economy. Rigging of election has resulted in the erosion of cherished cultural and electoral values such as hard work, dignity of labour, fairness, honesty, faithfulness, integrity, among others. Rigging brings wrong leaders into power who over the years do not want leave power but desired to rule for life. It has further affected the practice of democracy in Nigeria and hindered accountability and lucidity, resulting to bad governance (Ukwayi, Okpa, Adewoyin, Angioha, \& Udom, 2017).

\subsection{Misappropriation of Public Funds and Sustainable Development}

The term misappropriation of funds refers to the management methods and patterns that calculatively misuse wealth or financial resources provided for individuals in ways that are characterized as bad, careless and improper. According to Olalube (2016), misappropriation connotes to manage incompetently or dishonestly of anything put in one's care. The concept is synonymous with management ineptitude, incompetency, inefficiency, being managed badly, and dishonestly. ACID (2013), reported that the misappropriation of funds by public office holders in Nigeria has not only affected sustainable development but also heightened political tension and instability. Misappropriation of public funds according to ACID (2013) report is one of the major social ills plaguing the socio-economic development of Nigeria and other third world countries.

Tiamiyu (2012) posits that there is a lot of mismanagement of funds meant for development by government and political office holders in Nigeria, this ugly trend have led to appreciable number of uncompleted or abandoned projects across the country. For instance, political office holders particularly governors spend millions of naira planting flowers, constructing Christmas trees, feeding poultry birds when roads in their states are in terrible condition. Most of these leaders spend millions to purchase exotic vehicles for government officials, when hospitals and schools in their states are in deplorable conditions. This is a clear indication of goal misplacement and misplaced priority by these officials. Olalube (2016), noted that governments are interested in spending money on creation of new projects instead of completing, consolidating and expanding access to existing ones. He further reported that 
they are keen to award new contracts rather than completing the abandoned projects or standardizing existing facilities, possibly due to the desire to siphon or loot public funds for personal aggrandizement. Nigerian government (federal and states) expend hundreds of millions in mundane administrative cost instead of providing boreholes and power supplements (ASUU, 2016).

According to OSJI (2015), an estimated \$20-40 billion are stolen from public treasuries each year in developing countries, of which Nigeria ranked number one; out which, an estimated $\$ 5$ billion have been recovered and returned over the past 15 years. The report also revealed that between 2004 and 2006, Switzerland seized \$505.5 million from former president Sani Abacha and reparated the money to the Nigerian government. Agreement between the Swiss and Nigerian governments and the World Bank indicated that the money would be spent on Millennium Development Goal (MDG) projects related to health, education, water, electricity, and roads.

Nsikan and Emmanuel (2015), identified unfriendly policy implementations, inability to access funds, inconsistency and complete lack of courage to implement policies and mismanagement of funds by successive government and institutional leaders as the bane of Nigeria's development. Acho and Abuh (2016), observed that inspite of the complaints of poor funding allocation by Ministries, Departments, and Government Agencies in Nigeria, the little funds appropriated are mismanaged. According to Mobegi (2015), Ukwayi, Adewoyin, John, Ofem, (2017) any country where mismanagement of funds is significantly high, sustainable development is retarded. Nsikan and Emmanuel (2015), believed that Nigerian developmental challenges could be addressed through proper planning and effective administration of public funds. This is because no human institution can perform at it best without fundamental policy framework in its planning, organizing and controlling mechanism.

\subsection{Theoretical Consideration}

\subsubsection{System Theory}

System theory was proposed by Ludwig Von Bertalanffy (1940s) and expanded by Ross Ashby. The theory focuses on the arrangement of, and relations between the parts, which connect them to a whole. This framework is considered appropriate to this study in the sense that Nigeria's underdevelopment has been blamed on the dysfunctional role played by different governmental agencies, which has retarded growth and development in the country. The greed and insatiable quest for financial resource as well as the desire to win elections by all means, are strong factors that have strongly affected sustainable development. Electoral and economic crime constitutes the key factor underlying the continuing underdevelopment tragedy and the seemingly intractable sustainable development in Nigeria. The contention in this study is that economic and electoral crimes are contributory to the dysfunctionality in the survival of the Nigerian system. The presence of this problem has affected governance on one hand, as well as inhibits developmental strides on the other hand in Nigeria.

\subsubsection{Methodology}


The research design adopted for this study is the survey design. The design was opted for because of its relative importance in the collection of accurate information from respondents at relatively low cost and greater efficiency. In addition, the design allows for random sampling and purposive selection of respondents, and the use of questionnaires (Burns, 2000, Isangedighi, Joshua, Asim \& Ekuri, 2014). The study was carried out in Cross River State, Nigeria. Cross River is a state in Southern Nigeria sharing boundary with Cameroon in the east. Its Capital city is Calabar, with Boki, Ejagham, and Efik as their major languages.

The state is divided into three Senatorial District namely Southern, Central and Northern Senatorial Districts. The Southern Senatorial District consists of seven local government areas namely: Akamkpa, Akpabuyo, Bakassi, Biase, Calabar Municipality, Calabar South and Odukpani Local Government Areas. The Central and Northern Senatorial District is divided into six and five local government areas respectively. They include: Yakurr, Abi, Obubra, Ikom, Etung, Boki, Ogoja, Yala, Obanliku, Obudu, Bekwarra. According to National Population Census (2006), the projected population of Cross River State is three million, three hundred and forty four thousand, four hundred and ten (3,344,410 million) people. These consists of male and female, civil servants, farmers, artisans, students, among others.

The study adopted purposive sampling technique. This method was adopted because it allows the researcher to reach a targeted sample quickly. The study sample is three hundred and eighty four (384) respondents. From each of the three senatorial district one hundred and twenty eight (128) respondents were selected. The respondent consists of adult male, female and youths. Filled questionnaires were collated, coded and analysis using linear regression.

\subsubsection{Results}

For the data analysis, simple percentage, and chart was adopted.

\subsubsection{General Description of Data}

The instrument EECSDQ was administered to a sample of three hundred and eighty four (384) respondents selected from the three senatorial district of Cross River State. Extreme care was adopted in the administration and retrieval of the questionnaire, this resulted to the retrieval of three hundred and eighty one (381) questionnaires out of the three hundred and eighty four distributed. The questionnaire was distributed in INEC local government offices in the three senatorial district of Cross River State, political party offices, churches and some selected streets in Calabar, Ugep, Ikom, Ogoja and Obudu.

\section{Presentation of Results}

\subsection{Research Question One}

Research question one, states that to what extent does election rigging affect sustainable development in Cross River State? Fig 1 shows the responses of respondents to question one. As revealed in fig 1 all the respondents answered "Yes" to all the items in question one. From the respondent responses, 82.2 per cent $(\mathrm{N}=313)$ answered "Yes" to question one which states that rigging of election is the bane of sustainable development in Cross River State while 17.8 percent $(\mathrm{N}=68)$ answered "No". Responses on question two which states that sustainable 
development is not achievable in the face of continuous rigging of election brings the wrong leaders into power, 78.2 per cent $(\mathrm{N}=298)$ answered "Yes", while 21.8 per cent $(\mathrm{N}=83)$ answered "No". On question three which states that election rigging is often perpetrated by desperate politicians and their followers, 79.5 Per cent $(\mathrm{N}=301)$ responded "Yes" while 21.0 per cent $(\mathrm{N}=80)$ say "No" On question four which states that the politician engage in rigging of election for personal interest, 67. 2 per cent (256) answered "Yes" while 32.8 per cent $(\mathrm{N}=125)$ answered "No". This result therefore implies that rigging of election affects sustainable development in Cross River State, Nigeria. This to a large extent is true judging from the level of development in Cross River state. Although there are other factors that have hindered development in the state, from the findings of this study, rigging of election contributes to the underdevelopment in the state. Through rigging, wrong persons have emerged as leaders, whose focus and concern is to illegally enrich themselves at the expense of state's development. This has affected sustainable development in the Cross River State, Nigeria.

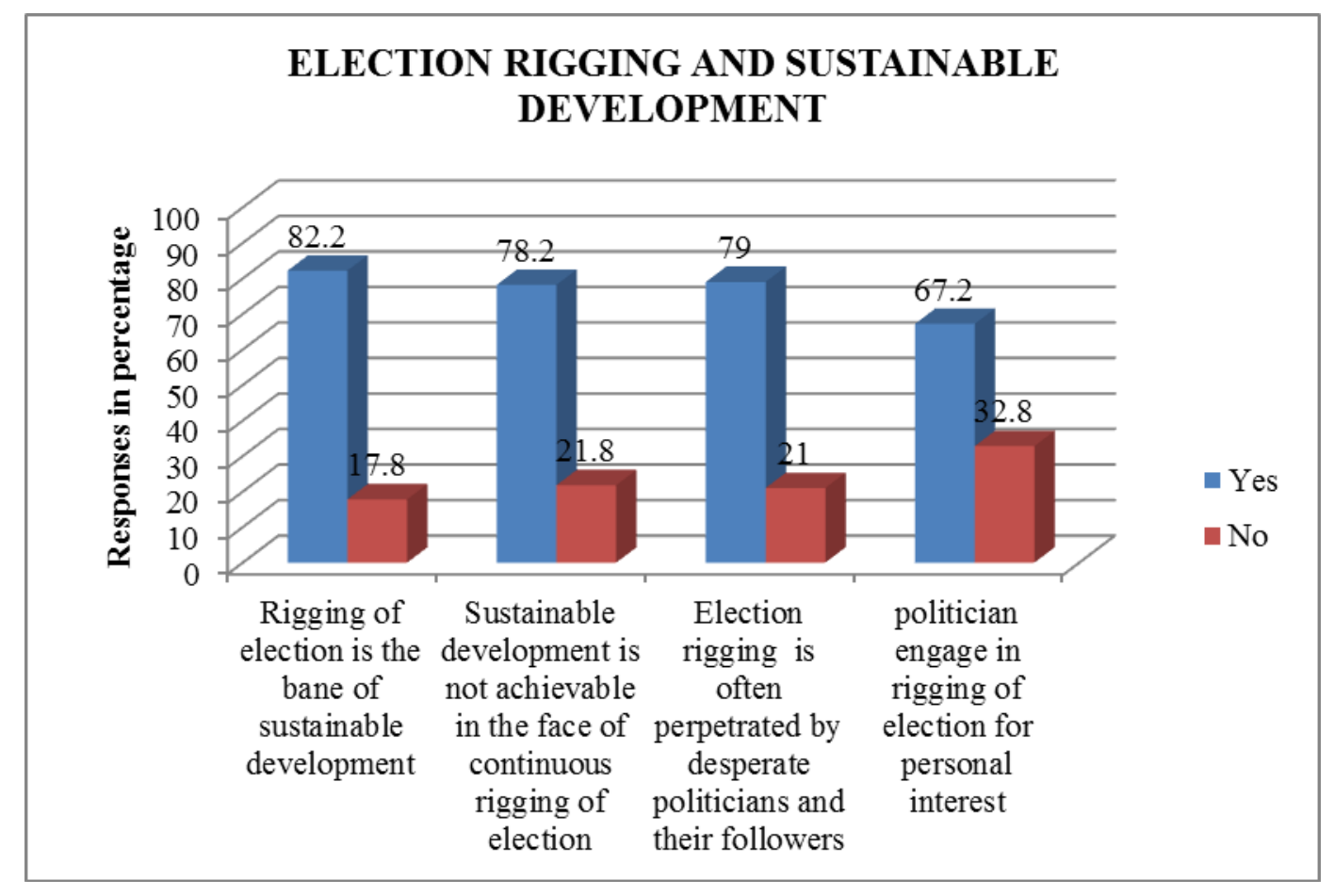

Figure 1. Cylinder bar chart showing the response of respondents on election rigging and sustainable development

\subsection{Research Question Two}

Research question two states that how does misappropriation of public funds affect sustainable development in Cross River State, Nigeria. Fig 2 shows the responses of respondents to question two. As revealed in fig 2 all the respondents answered "Yes" to all the items in question two. From their responses, 78.5 per cent $(\mathrm{N}=299)$ answered "Yes" to 
question one which states that diversion of funds budgeted for infrastructural facilities affects sustainable development while 21.5 percent $(\mathrm{N}=82)$ answered "No". Responses on question two which state that misappropriation of public funds is a major challenge to the actualisation of sustainable development shows that, 79.0 per cent $(\mathrm{N}=301)$ answered "Yes", while 20.9 per cent $(\mathrm{N}=80)$ answered "No". On question three which states that sustainable development is realistic when funds are properly appropriated, 95.5 Per cent $(\mathrm{N}=364)$ responded "Yes" while 4.4 per cent $(\mathrm{N}=17)$ say "No" On question four which states that the failure of the public office holders to judiciously manage the country resources has led to infrastructural deficit, 81. 1 per cent (309) answered “Yes” while 18.9 per cent (N=72) answered “No”. This result therefore implies that misappropriation of funds affects sustainable development in Cross River State, Nigeria.

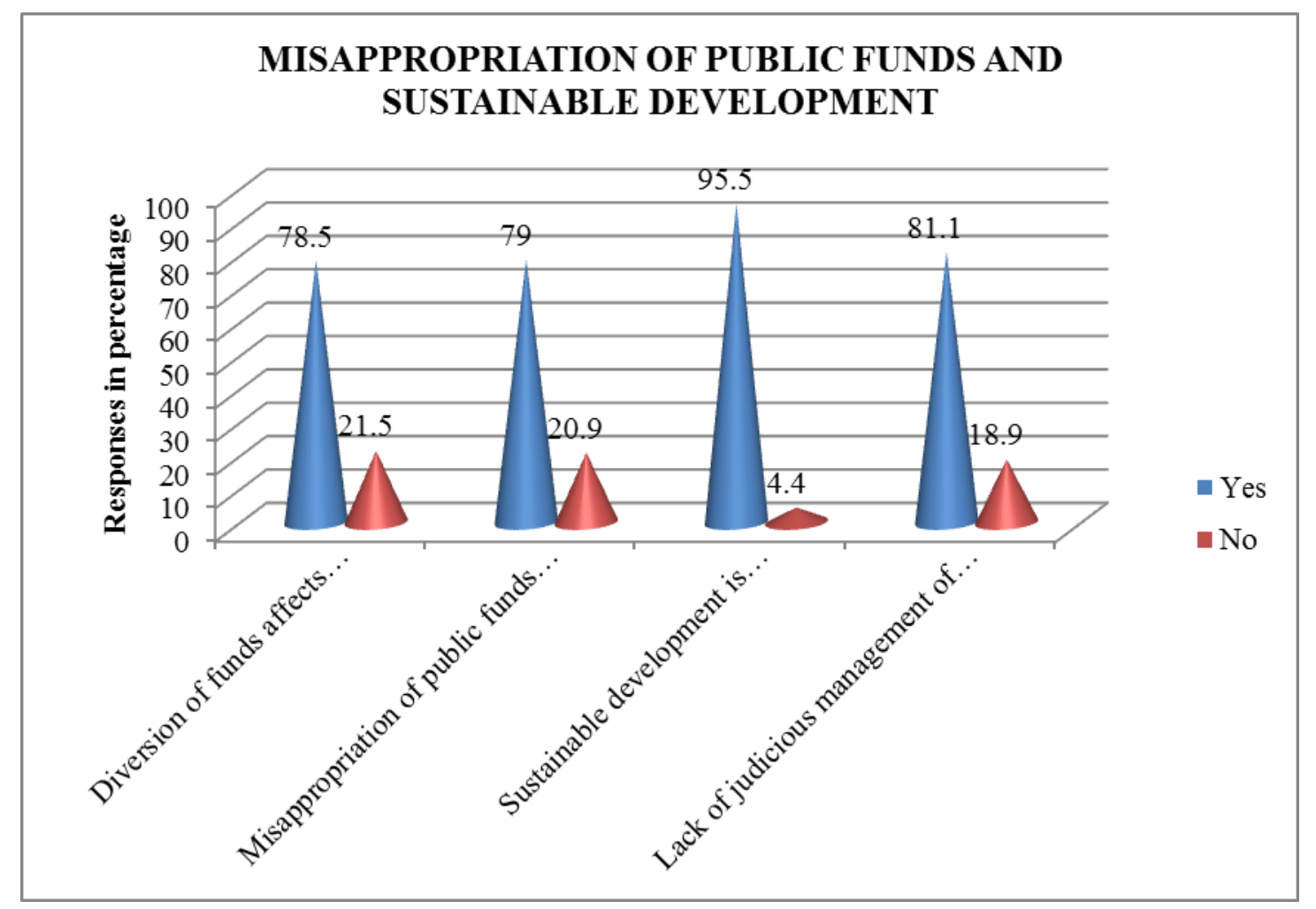

Figure 2. Pyramid bar chart showing the response of respondents on misappropriation of public funds and sustainable development

\section{Discussion of Finding}

\subsection{Misappropriation of Public Funds and Sustainable Development}

Findings of this study indicate a significant relationship between misappropriation of public funds and sustainable development in Cross River State, Nigeria. It reveals that diversion of funds budgeted for infrastructural development affects sustainable development. It shows that 
asset misappropriation is a major challenge to the actualisation of sustainable development. More so, the study reveals that sustainable development is realistic when funds are properly appropriated. It suggests that the failure of the political class to judiciously manage the country's resources has led to infrastructural deficit. ACID (2013) reported that the misappropriation of funds by public office holders in Nigeria has not only affected sustainable development but also heightened political tension and instability.

Similarly, Tiamiyu (2012) posits that there is a lot of mismanagement of funds meant for development by government and political office holders in Nigeria, this ugly trend have led to an appreciable number of uncompleted or abandoned projects across the country. According to Mobegi (2015), any country where mismanagement of funds is significantly high, sustainable development is retarded.

\subsection{Election Rigging and Sustainable Development}

The statistical analysis of hypothesis two revealed that election rigging significantly affects sustainable development in Cross River State, Nigeria. The study shows that rigging of election in Nigeria has persisted and grown in magnitude. According to ACID (2013) the failure of politicians and their supporters to abide by electoral laws and play the game by the rules has partly been responsible for poor socio-economic development and military intervention in politics. These electoral evils has created unhealthy political atmosphere that negatively affects sustainable development. This finding corroborates earlier work by scholars. They observed that electoral malpractices such as rigging have been one of the most impediments to sustainable development. It has led to political instability and has affected all spectrum of the Nigerian economy. Rigging of election has resulted in the erosion of cherished cultural and electoral values such as hard work, dignity of labour, fairness, honesty, faithfulness, and integrity.

\section{Conclusion and Recommendations}

The focus of this study was to examine the effect of electoral and economic crimes on sustainable development in Cross River State, Nigeria. Specifically, the study investigated the relationship between misappropriation of public funds, rigging of election and sustainable development. After an extensive analysis, the study concluded with a number of assertions that misappropriation of public funds, rigging of election significantly affects sustainable development in Cross River State, Nigeria. Based on these findings, the following recommendations were made:

(i) Political office holders should judiciously utilize public funds for programmes and projects that would positively affect the well-being of the citizens.

(ii) Rigging of elections should be made a capital offence with severe punishment such as life imprisonment and death sentence.

(iii) Effective internal control measures should be established in all identified areas of asset abuse to minimize incidences. 


\section{References}

Acho, Y., \& Abuh, P. A. (2016). Corruption and accountability in the Nigerian public sector: An empirical discourse. International Journal of Public Administration and Management Research, 3(3), 47-54.

ACID. (2013). Corruption control and political stability in Nigeria: implication for value re-orientation in politics. A report submitted to sunshine progressive youth, Lagos, Nigeria.

ASUU. (2016). Facts and figures: real reasons behind ASUU strike. Retrieved November 20, 2016 Retrieved from http://www.naijaperminute.com.ng/2016/11/20/ facts-figures-real-reasonsbehind-asuu-strike/

Ayobolu, J. (2006). EFCC, Corruption and the Due Process. USA: Segun Toyin Dawodu.

Burns, R. (2000). Introduction to research methods. London: Sage.

Desta, Y. (2006). 'Designing Anti Corruption strategies for developing countries': A country study of Eritrea. Journal of Developing Societies, 4, 421-449.

Dike, V. (2008). “Corruption in Nigeria: A new paradigm for effective control” African Economic Analysis. Retrieved from www.africaeconnomicanalysis.org

Inokoba, P. K., \& Ibegu, W. T. (2011). Economic and Financial Crime Commission (EFCC) and Political Corruption: Implication for the Consolidation of Democracy in Nigeria. Anthropologist, 13(4), 283-291.

Isangedighi, A. J., Joshua, M. T., Asim, A. E., \& Ekiri, E. E. (2014). Fundamental of research and statistics in education in education and social science. Calabar. University of Calabar Press.

Mobegi, F. O. (2015). Perceptions of educational stakeholders regarding the effects of financial mismanagement on physical facilities in secondary schools in Gucha District, Kenya. International Journal of Social Science and Economics Invention, 1(3), 1-18.

Mustapha, M. A. (2008). "Combating corruption in Nigeria: The role of the Legislature Examined”. The University of Ilorin Law Journal, 3(4), 57-79.

Okpa, J. T., \& Ukwayi, J. K. (2017). Drug suspects perception of factors responsible for illicit drug trade in Cross River state, Nigeria. IOSR Journal of Humanities and Social Sciences, 5(4), 80-87.

Ololube, N. P. (2016). Education Fund Misappropriation and Mismanagement and the Provision of Quality Higher Education in Nigeria. International Journal of Scientific Research in Education, 9(4), 333-349.

Omadjohwofe, O. S. (2014). Corruption and sustainable development in Nigeria: The imperative of a trado religious anti-corruption strategy. International Journal of Business and Social Sciences, 5(1), 223-230.

OSJI. (2015). Background briefing on repatriating stolen assets: potentials funding for 
sustainable development. A civil society side-event at the 3rd International Conference on Financing for Development, Addis Ababa.

Pogoson, I. (2009). Globalisation and anti-corruption reform in Nigeria: 2003-2007. In Enweremadu \& Okafor (eds.) Anti-corruption reforms in Nigeria since 1999: Issues, challenges and the way forward. Ibadan: IFRA Special Research Issue.

Sachs. G. (2007). Corruption remains Nigeria's long term challenge. The Daily Independent Newspapers Tuesday, 24 April 2007.

Tiamiyu, R. A. (2012). Questioning the claim of inadequate funding of tertiary education in Oyo State, Nigeria. International Journal of Governmental Financial Management, 2(4), 46-61.

Ukwayi, J. K., Okpa, J. T., Adewoyin, S. A., Angioha, P. U., \& Udom, H. T. (2017). Security equipment and policing in central senatorial district of Cross River state, Nigeria IOSR. Journal of Humanities and Social Sciences, 22(2), 6-13.

Ukwayi, J. K., Adewoyin, S. A., John, T. O., Ofem, N. O. (2017). Public perception of small arms epidemic and conflict in Oke-Ogun area of Oyo State, Nigeria. The International Journal of Humanities \& Social Studies, 5(2), 100-108.

\section{Copyright Disclaimer}

Copyright for this article is retained by the author(s), with first publication rights granted to the journal.

This is an open-access article distributed under the terms and conditions of the Creative Commons Attribution license (http://creativecommons.org/licenses/by/3.0/). 